\title{
MECHANISMS OF SUPPORT FOR THE YOUNG RURAL POPULATION IN THE EUROPEAN UNION
}

\author{
Katarina Đuric ${ }^{1}$, Zoran Njegovan ${ }^{2}$
}

\begin{abstract}
Summary
The main goal of this paper is an overview of existing and future mechanism of supporting young farmers in European Union. Positive effects of the measures of rural development policy, as well as restrictions in their operationalization were analyzed based on the insight into current reference sources and the regulations of European Union. Key recommendations for rural development policy regarding youth pertain to a higher degree of youth participation in the creation of development programs and projects, simplification of administrative procedures and a greater availability of information. Specific restrictions for potential young farmers include difficult access to farming land and a system of financing based on the refunds of invested resources.
\end{abstract}

Key words: rural development policy, European Union, young farmers, rural population JEL: $Q 10, Q 18$

\section{Introduction}

Demographic changes and a reduction of rural population numbers are important issues that most EU countries deal with, primarily due to the strong influence that these questions have regarding the economic performance of rural areas. In the coming years, the share of the working-age population in the total population will start to decline in all countries of the European Union. All other things remaining equal, this so-called demographic burden will have a downward effect on economic growth (Van Dr Gaag and de Beer, 2015). One of the key priorities of rural development policies in the EU is the support for young people to stay in rural areas. The share of population between 15 and 65 years old is always significantly higher in urban areas and the proportion of old people (65 years old and more) is often slightly higher in predominantly rural areas (Camburu, 2010). Out of the total agricultural population of EU, young people make up only $6 \%$. Also, the term "young farmer" implies a person of up to 40 years of age who is starting to work in agriculture at his/her newly established or inherited farm, possessing capabilities to

1 Katarina Đurić Ph.D., Assistant Professor, Faculty of Agriculture Novi Sad, Dositeja Obradovića square no. 8, Novi Sad, Phone: +381 2148532 32, E-mail: katarina.djuric@polj.uns.ac.rs

2 Zoran Njegovan, Ph.D., Full Professor, Faculty of Agriculture Novi Sad, Dositeja Obradovića square no. 8, Phone: +381 2148533 93, E-mail: njegovan@polj.uns.ac.rs

EP 2015 (62) 4 (1003-1016) 
improve the farm and manage it in accordance with standards of ecology, hygiene and animal welfare (EU regulation 1257/99). In order for the villages to possess the capacity for sustainable development, it is necessary to achieve affirmation for young people in rural areas, primarily through means of economic motivation.

The support to young farmers in EU is accomplished through the resources of European Agricultural Fund for Rural Development. Resources from this fund are routed towards future young farmers the 'setting-up of young farmers' measure, which supports establishing a new farm and starting its business. These subventions are aimed, primarily, at the goal of helping young people, future farmers, to successfully deal with all the challenges waiting for them upon entering the agricultural sector. This and other measures of rural development policies were created in order to provide support and encouragement for young people to stay and do business in a rural environment by creating possibilities of employment and promotion of services and infrastructure development which is positively influencing the social and economic vitality of the rural areas. Also, different types of support are realized within the national programs of rural development of each of the member countries. Help for young farmers such as training, advice and easier access to information are the most common ways of support realized at a national level.

\section{Materials and methods}

Considering the subject and goal of this research, the method of descriptive analysis is the most applied one, based on studying current reference sources and legal regulations of European Union. Reference sources served to create an insight into research done so far and experience regarding the measures of rural development policy intended for younger population. Method of comparative analysis is also applied significantly, considering the necessity of the overview of advantages and limitations when it comes to supporting young farmers in the previous $(2007$ - 2013) and the future $(2014-2020)$ program period.

Efficiency evaluation of support measures for young rural population, as well as determination of the significance of this segment of rural development policy, represent the basis for an overview of supporting aspects of future young farmers of European Union in the following seven-year period.

\section{Rural development policy of the European Union and the support form young farmers in the 2007-2013 period}

Motivation of young people in rural areas to engage in agriculture and other nonagricultural activities in the period from 2007 to 2013 was operationalized by agricultural policy and rural development policy of the EU. Some measures were developed in order to have a direct influence on the economic motivation of young farmers to establish their own farms, while other measures indirectly influenced the improvement of the capacities of rural youth and took their knowledge and abilities to a higher level. 
A measure that represents direct support for the young farmers is measure 112 - setting up of young farmers. It is common for all member countries that this measure is aimed at the population of up to 40 years of age. Total resources secured for helping young farmers to start their businesses for the 2007 - 2013 period were $€ 4.82$ billion from the European Agricultural Fund for Rural Development and $€ 1.98$ billion from national budgets (ERDF, 2014). From the total authorized amount, until December 2013, 75.8\% of the resources was allocated to the projects (Zagata and Sutherland, 2015). Allocation of spent resources according to countries is as follows: France $-€ 1.6$ billion, Italy - $€ 700$ million, Spain - $€ 561$ million, Poland - $€ 392$ million, Romania $€ 302$ million. Until the end of the accounting period, i.e. until December 2013, more than half of the member countries did not use the entire amount of resources intended for financing this measure. Data from 2013 shows that on the level of the Union a total of 126,000 young farmers used these subventions intended for starting a farming business, the largest number of them being from France, Poland, Italy, and Romania (ERDF, 2014). Measure 112 was aimed at farms run buy young farmers whose goal is increasing production capacities and modernizing farms. Also, this measure, as Slovenian experience shows, stimulates the transfer of farms from older to younger generations of farmers (Hočevar-Knežević, 2012). At the same time, a global comparison shows that, in 2010, the average financial support per one person employed in agriculture totaled 6574 euro in the EU-27 (Ciutacu et all., 2015).

Second measure intended for young farmers is measure 121 - modernization of agricultural farms. This measure exists in all programs of rural development of EU member countries. Basically, measure 121 is supported by all farmer categories, however, some rural development programs connect subvention approval with specific criteria when farmers up to 40 years of age are in question. A good example of this is the Netherlands which defined a sub-measure 121A which provides support from agricultural investment by young farmers. The condition that farmers have to fulfill in order to apply for using the resources from measure 112 is a finished agricultural high school or three years of work experience. In order to provide more favorable conditions and thus motivate future young farmers, Finland, within its national program of rural development, defined a sub-measure whereby young people are allowed a grace period of 36 months in order to fulfill the conditions regarding education or work experience.

Third measure, affirmative for young farmers, is measure 111 - vocational training and information actions. In Hungary and Romania, young farmers who are using resources from measure 112 are obliged to take part in training organized within measure 111 . Even though organizing vocational training does not pertain exclusively to young farmers, in some EU countries the resources intended for financing measure 111 are mostly used for organizing workshops and seminars for this farmer category.

Other measures of rural development influencing the position and perspectives of young farmers in most EU countries is realized through programs within Ose 3 and LEADER programs. Stand-out measures in this group are:

- Measure 321 - basic services for the economy and rural population. By 
applying this measure Finland and Sweden are fighting against the migration of young population from rural areas into cities. Through various activities organized by resources intended for measure 321, not only employment and vocational training in agriculture are accentuated, but also the improvement of the possibility for using cultural and recreational content. By investing into rural infrastructure, these two countries are trying to motivate young people to stay in the villages/towns.

- Measure 311 - diversification of non-agricultural activities. Some countries of EU, such as Sweden, recognized this measure as a tool for promoting sustainable possibilities of employment, especially for young farmers. Farm businesses working on production and sales of products which are not directly in connection with primary agricultural production are also encouraged by this measure. This measure is designed to create conditions for alternative sources of income and employment for farmers and their families, and also to create benefits for broader community (Vapa-Tankosić and Stojsavljević, 2014).

- Measure 312 - support for the creation and development of micro-enterprises. Special attention is paid to young people organizing their own work. Romania defined in its national program of rural development a specific criterion within measure 312 where priority is given to women of up to 40 who live in rural areas and are interested in starting their own company. The existence of this measure proves the determination of the EU, as can be seen from the policy framework where two critical groups or rural population for achieving economic and social cohesion are the youth and women (Kazakopulos and Gidarakou, 2003). Similar to this, youth and women in rural areas are support via measure 313 - encouraging activities in tourism.

- Young rural population is the target group for both measure 331 - training and information and measure 421 - inter-territorial and transnational cooperation. Belgium, Poland, Sweden, Estonia and Great Britain apply these measures in order to encourage young population to stay in rural areas.

Apart from an institutional support to the young rural population which is financed by European Union by way of a mechanism of measures within the second pillar of Common Agricultural Policy, development programs and projects intended to encourage young people to stay in rural areas are realized at a national level. This development concept which equally consolidate social, ethical, ecological and economic dimension are more and more desirable. It demand networking of different scientific areas, pluralism of thoughts and consensus of actiong based on communication, tolerance and solidarity (Tolić and Pušić, 2010). Starters of this type of projects are in most cases local action groups and associations. Other initiators of the project are representatives of national, regional, or local authorities, as well as private initiatives from large private companies, universities and national networks for rural development. Organization and pooling together of young people in rural areas, as well as young farmers, was recognized by 
most countries of European Union as a very important factor of their successful active involvement in the process of creation and operationalization of the policy and program of rural development (ENFRD, 2013).

\section{Positive and negative points of rural development policy from the aspect of young farmers of the European Union}

Efficiency of every policy is measured, among other things, by the quality of the system of its evaluation. Considering this, a workshop was held in Brussels on December $11^{\text {th }}$ and $12^{\text {th }} 2013$, organized by the Initiative on youth and young farmers in rural areas, attended by representatives of all the countries of European Union. From a total of 161 participants, 51\% were young farmers, 37\% were rural youth, 29\% representatives of EU institutions, while other participants were representatives of authorities, national rural development networks and other relevant subjects. Presentation of examples on the project and initiatives success via discussions, the workshop allowed the youth to talk about key questions they are dealing with as inhabitants of rural areas. The goal of the workshop was to point out positive sides, as well as limitations that young farmers came up against regarding the policy and programs of rural development in the previous period. Based on the conclusions of this workshop and other means of evaluation, European network for rural development published an evaluation of the effects on rural development policies from the aspect of youth.

Table 1. Advantages and limitations of rural development policy in the period from 2007 to 2013 from the aspect of rural youth in European Union

\begin{tabular}{|c|c|}
\hline Advantages & Limitations \\
\hline $\begin{array}{l}\text { Increasing the degree of involvement of youth in } \\
\text { the programs of rural development } \\
\text { - } \text { Recognition of youth as a target group in } \\
\text { development strategies } \\
\text { - } \begin{array}{l}\text { Participation of youth in defining the } \\
\text { program of rural development }\end{array}\end{array}$ & $\begin{array}{l}\text { Increasing the degree of youth participation in the } \\
\text { programs of rural development } \\
\text { - Low level of rural youth participation } \\
\text { in the application of rural development } \\
\text { programs }\end{array}$ \\
\hline $\begin{array}{l}\text { Recognition of young population as the target } \\
\text { group of rural development policy } \\
\text { - Specific criteria for approval and } \\
\text { financing of rural development projects } \\
\text { intended for young people }\end{array}$ & $\begin{array}{l}\text { Recognition of young population as the target } \\
\text { group of rural development policy } \\
\text { - Young people often do not have an insight } \\
\text { in the programs of rural development }\end{array}$ \\
\hline $\begin{array}{l}\text { Strengthening rural youth } \\
\text { - Simplifying administrative procedures } \\
\text { for projects with a small budget or } \\
\text { umbrella schemes } \\
\text { - Organizing training in project and } \\
\text { entrepreneurship development }\end{array}$ & \begin{tabular}{|l} 
Strengthening rural youth \\
$-\quad$ Youth often do not direct projects \\
intended for them \\
- Complex administrative procedure, large \\
bureaucracy and financing problems
\end{tabular} \\
\hline
\end{tabular}

Source:http://enrd.ec.europa.eu/enrdstatic/app templates/enrd assets/pdf/youth and young farmers/workshop/YouthWorkshopReport_web.pdf 
Facts such as that rural youth is not represented enough at a local level of the authorities, i.e. not participating enough in the process of decisions is stated as the greatest obstacles for increased youth participation in creating and realizing the policy of rural development, as well as the fact that some countries (Estonia, Netherlands, Cyprus) lack strong organizations of young farmers. The result of insufficient participation are projects and initiatives designed for young people, not by young people. The expectations of young people and young families in rural areas are diffiernt to those of previous generations. Creating a social and community framework that meets those expectations is an integral part of effective rural development (Ali et all, 2011).

In order to increase the efficiency of this type of projects in the future accounting period, it is necessary to achieve a higher degree of cooperation between the participants, in the planning process, as well as all the phases of project realization. This type of coordination was not present enough in the 2007 - 2013 period, which is considered one of the flaws of EU rural development policy.

Lack of information on the sources of financing, as well as a broad and complex administrative procedure have been recognized by the youth as a restricting factor for design, application and implementation of projects. Long waiting periods for the decisions on project approval and frequent changes of rules also represent limitations pointed out by young farmers' population. Rules of project financing imply a system based on the refund of invested resources. This implies that in order to realize a project one must take a loan, which is unfavorable to young farmers considering their limited abilities of securing a loan via guarantees or mortgages.

Lack of experience in working on projects is a serious limitation for young farmers, from applying for a project to its implementation. Lack of management knowledge limits young farmers in the process of starting up their own business, i.e. a new agricultural farm. Existing education system in most EU countries does not provide enough training concerning actual business market, which is a serious drawback for future young farmers. Recommendations state that new farmer generations should be given basic knowledge in environment protection, multi-functionality, diversification of agricultural activities on a farm, organic farming and other relevant questions that they might encounter in reality, all that through the education system.

Access to farming land is seen as a key limitation for future young farmers. In some EU countries, such as Ireland, farmers retire at a very old age, preventing the young farmers' access to land. Situation is additionally complicated due to the fact that large farms are given significant subventions so that the owners of such land, which might not be used for farming at all, do not want to sell it. Price of land, tax system, as well as European and national regulations add to the problem of young farmers obtaining land, which hinders the creation of new farms. 
Table 2. Suggestions and recommendations for the implementation of rural development programs in the future

\begin{tabular}{|l|l|}
\hline $\begin{array}{l}\text { Recommendations for rural development policy } \\
\text { creators } \\
\text { (ministries, national rural development networks, } \\
\text { local action groups) }\end{array}$ & $\begin{array}{l}\text { Recommendations for rural youth and their } \\
\text { organizations }\end{array}$ \\
\hline $\begin{array}{l}\text { Use of pro-active and long-term approach when } \\
\text { targeting rural youth while planning development } \\
\text { strategies }\end{array}$ & $\begin{array}{l}\text { Active promotion of subjects regarding the position } \\
\text { of youth in rural areas }\end{array}$ \\
\hline $\begin{array}{l}\text { Securing a higher degree of cooperation between } \\
\text { rural youth and decision makers at all levels }\end{array}$ & $\begin{array}{l}\text { Improving connection, cooperation and an } \\
\text { exchange of experiences }\end{array}$ \\
\hline $\begin{array}{l}\text { Securing an easier access to financial sources, } \\
\text { advice agencies and information. }\end{array}$ & $\begin{array}{l}\text { Improving knowledge in project proposals and } \\
\text { project management }\end{array}$ \\
\hline $\begin{array}{l}\text { Encouraging and supporting projects designed by } \\
\text { young people, and not only projects designed for } \\
\text { young people }\end{array}$ & Supporting the dissemination of information \\
\hline $\begin{array}{l}\text { Appreciation of the voice of young people at a local } \\
\text { level }\end{array}$ & $\begin{array}{l}\text { Informing policy creators regarding ideas, needs } \\
\text { and challenges that await young people in rural } \\
\text { areas }\end{array}$ \\
\hline
\end{tabular}

Source:http://enrd.ec.europa.eu/enrdstatic/app templates/enrd assets/pdf/youth and young farmers/workshop/YouthWorkshopReport_web.pdf

Based on the experience of EU countries in implementing rural development policy 2007 - 2013, the following success factors from the aspect of rural youth stand out:

\section{Inclusion of young people in rural development policy at a local, regional and national level:}

- Active inclusion of young people in strategic document development at EU, national, regional and local level should be one of the priorities. Active participation is the best way to bring concrete problems of young farmer population into development documents.

- SWOT analysis of the position of youth in rural areas proved to be a solid basis for recognizing the problem and defining measures for the most effective solution to those problems.

- Considering that rural youth are highly heterogeneous, when developing and implementing development documents it is necessary to respect the differences in needs and problems of young farmers and non-agricultural young population.

- Cooperation between young people within local action groups, as can be seen in Sweden and Great Britain, has proven to be one of the key factors of successful work at a local, as well as regional and national level.

- Strengthening of organizations that gather various categories of young people (farmers, entrepreneurs, students, etc.) has proven itself as a significant step 
towards a higher degree of inclusion of young people in social life. However, inadequate financial support for start-up and work, with human capital that is not established and a lack of highly motivated young leaders is limiting the options for creation and work of such organizations.

\section{Financial improvements:}

- It is necessary to increase the degree of cooperation between various financial sources for the program and projects of rural development intended for young people. The degree of coordination needs to be improved in order to increase the efficiency of use regarding funds at disposal and to avoid overlapping.

- Information on financial sources have to be accessible by young rural population. Optimal solution would be to forma one source of information regarding all sources at disposal and the resources granted by them.

\section{Simplification of administrative procedures:}

- Simplification of the procedure for project application would encourage not only young farmers but all other categories of potential users of funds.

- Forming specific advisory services that would provide support for young people during the implementation of the project is considered one of the key factors of success for rural development policy in the future period.

\section{Active participation in development projects:}

- Inclusion of young people in the design of the project is considered a key factor for success. Creation and management of the project by young rural population has proven to be an important success factor. "If young people feel like guests on the projects, they will not feel welcome and they will not stay on the project. If, on the other hand, they are given the opportunity to make decisions and bear responsibility, they will see the project as their own and will put in all their capacities to make sure the project is successful" (ENRD, 2014)

- Hiring a trainer for young people within the local action groups would increase the chances of success of the rural development policy, i.e. the program intended for young rural population. The task of the trainer would be to work with young people, communicate their problems and expectations to local action group and work on their education and provide information. This would allow for coordination between trainers in different regions of a country, which would bring about better understanding of youth problems and would improve their position in rural areas.

\section{Advancing knowledge and skills:}

- Advancing knowledge and skills of young people is crucial for their active and purposeful engagement in rural development. Improvement of knowledge and skills, i.e. capacity building, can include different areas, 
from project application to entrepreneurial activities.

\section{Providing information:}

- An important success factor for rural development policy is the availability of information on development possibilities and good experiences. Types of providing information should be in line with the habits of potential users of such information. Creating particular websites and smartphone applications would allow for an easier dissemination of information among young farmers population.

- Introducing young famers to the projects that have yielded good results in different EU countries would serve as an encouragement for design and realization of potential new projects.

Key problems for young rural population, regardless of whether it is focused on agriculture or some other type of activity, in most EU countries are: unemployment, limited opportunities to join social activities and undeveloped infrastructure. Following the above stated recommendations for rural development policy in the future program period would create a solid platform for solving fundamental problems of the young rural and farming population of EU.

\section{EU rural development policy 2014-2020}

EU rural development policy continually shifts following the changes in rural areas. In accordance with the regulations of the development document "Europe 2020" and the general goals of Common Agricultural Policy 2014 - 2020, three long-term goals of rural development policy are as follows:

1. increasing competitiveness of agriculture;

2. sustainable management of resources and taking action against climate change, and

3. balanced territorial development of rural households and communities, including the creation and retention of work places.

Without changing the system applied in the previous period, EU rural development policy 2014 - 2020 will be realized through national and/or regional rural development programs lasting seven years. The novelty in rural development policy starting from 2014 is:

- improvement of the strategic approach to the development of national and regional programs of rural development;

- improvement of the content of rural development measures

- simplification of rules and/or reduction of administrative procedure regarding rural development programs in cases where this is possible, and

- $\quad$ stronger bond between rural development policy and European Structural and 
Investment Funds

In the period 2014 - 2020, EU rural development policy has the following six priorities:

- improvement of knowledge and innovation transfer in agriculture, forestry, and rural areas;

- increase in competitiveness of all types of agricultural practice, as well as the use of new technologies in agricultural production and sustainable forest management;

- organization of a food supply chain, carrying out of activities regarding animal welfare and risk management in agriculture;

- regeneration, preservation and improvement of ecosystems closely connected with agriculture and forestry,

- promotion of efficient use of resources;

- reduction of poverty and improvement of economic development in rural areas through social inclusion (EC, 2014).

Within each of the stated priorities the so-called 'areas of interest' are defined, i.e. certain more detailed areas of intervention. Based on a comprehensive analysis of needs, every member country or region decides their own areas of interest and implements them in the national program of rural development. Programs define concrete measures for achieving the goals and the amount of resources to be allocated to each measure as well. Rural development policy measures are financed partially from European Agricultural Fund for Rural Development and partially from national, regional and private sources. Execution and efficiency of rural development policy is followed and evaluated.

Program period 2014 - 2020 foresees an extension of support for young people in rural areas through subventions for setting up their own farms and starting agricultural businesses (measure 112 - 'setting-up aid'). Member countries can include thematic sub-programs in their national rural development programs regarding the support for young people in rural areas. Within the sub-program, the following types of support are provided:

- business setting-up subventions;

- farm starting subventions;

- physical infrastructure subventions;

- knowledge and information transfer;

- advisory services;

- farm management services;

- pooling together, and

- investing in non-agricultural activities (EU regulation 1305/2013). 
Within the measure that provides subventions for building a physical infrastructure, farmers up to 40 years of age are provided up to $20 \%$ higher amount than in other farmer categories. Help for young farmers for starting their own business, i.e. for setting-up a farm was planned in amounts up to $€ 70,000$ and will be paid as part of 'farm and business development' measure (EU regulation 1305/2013).

Support for young farmers, however, is not limited only to EU regulation 1305/2013. It is planned, as in the previous planning period, that various types of support be realized through individual programs of rural development and local development strategies. Some countries, such as Austria, Italy, Poland, Slovakia, Sweden, and Great Britain have already started, half-way through the previous planning period, the preparations and consultations regarding the participation of young farmers in creating rural development policy for the 2014 - 2020 period. In Austria and Slovakia young farmers are actively participating in workgroup activities planning development programs intended for young farmers, small farms and diversification of economic activities on farms. With the goal of stopping the outflow of young people from rural areas, Poland has planned, in the following period, a higher degree of engagement of local action groups in the process of inclusion of young people in various development programs.

\section{Conclusion}

Agriculture represents the dominant economic activity in rural areas of European Union. Such economic structure creates the need for mechanism in Common Agricultural Policy measures which will directly and economically motivate young people to stay in rural areas. Considering that people represent the key potential of every development, including rural, the importance of increase in human capital in rural areas is emphasized. Stimulating young farmers to stay has a direct positive influence on establishing steady territorial development, i.e. reducing economic differences between rural and urban areas of European Union (Marković et all., 2012). Apart from this, it should be taken into account that the age of the farmers influences their relationship with the concept of sustainable development of agriculture and a clear orientation towards efficient agriculture which also respects the standards of environmental protection and animal welfare.

The existing system of support for young rural population in European Union is continued in the 2014 - 2020 program period. Apart from positive effects that the policy of rural development ensured for young farmer, there are certain obstacles in the way of their stronger economic motivation for staying in rural areas. Success factors of rural development policy imply active participation of young people at the national, regional, and local level, improvements in the area of financing, simplification of administrative procedures, advancement of knowledge and skills, as well as a more efficient system for providing information. With these recommendations, which will be a part in European rural development policy in the future, it is more than desirable to promote agriculture as a sustainable contemporary business, and not just a traditional activity, while pointing out its social importance. Allocation of funds for rural development should increase, mainly for economic but also helth, political and social reason (Andrić et all., 2011). 
It is especially important to point these promotional activities towards young female population in order to increase the number of female farmers in EU. In the end, the importance of this topic can be heard in the words of Dacian Ciolos, former European Commissioner for Agriculture and Rural Development, stated at the meeting of the European Council of Young Farmers, where he point out that: 'If agricultural policy does not secure perspective for young farmers, we can only ask ourselves whether there is a future for European agriculture at all.'

\section{References}

1. Ali, S., Lungu, O. M., Calomfir, A. M. (2011): Rural development from rural womens perspective, Economics of agriculture, SI-1 (1-368), pp. 27-32

2. Andrić, N., Tomić, D., Vlahović, B. (2011): The role of European agricultural fund for rural development, Agrarian and Rural Policy in Serbia, Thematic Proceedings, Serbian Association of Agricultural Economist, Faculty of Economics, University of Novi Sad, pp. 11-23

3. Camburu, V. G. (2010): Socio-economic gap within the European Union, Economics of agriculture, SI-2 (1-656), pp. 79-93

4. Ciutacu, C., Chivu, L., Andrei, L.V. (2015): Similarities and dissimilarities between the EU agricultural and rural development model and Romanian agriculture, Challenges and perspectives, Land Use Policy No. 44, pp. 169-176

5. European Commission-EC (2014): Rural Development 2014-2020, 2014 Available at: http://ec.europa.eu/agriculture/rural-development-2014-2020/index en.htm

6. European Commission-EC (2010): Communication from the Commission, Europe 2020, A strategy for smart, sustainable and inclusive growth, Brussels

7. European Commission-EC (2010): The Common Agricultural Policy after 2013 - Your Ideas Matter, The Common Agricultural Policy after 2013, Public debate, Summary Report, Brussels

8. European Commission-EC (1999): Council Regulation No 1257/1999 of 17 May 1999 on support for rural development from the European Agricultural Guidance and Guarantee Fund (EAGGF) and amending and repealing certain Regulations, available at: http://eur-lex.europa.eu/legal-content/EN/TXT/PDF/?uri=CELEX:31 999R1257\& from=en

9. European Network for Rural Development-ENRD (2014): Youth and Young Farmers Thematic Initiative - Final Report, http://enrd.ec.europa.eu

10. European Network for Rural Development-ENRD (2013): Youth Workshop Report, available at: $\quad$ http://enrd.ec.europa.eu/enrdstatic/app templates/ enrd assets/pdf/youth and young farmers/workshop/YouthWorkshopReport web.pdf

11. European Parliament: Annex IV of Regulation (EU) no 1305/2013 of the European Parliament and of the Council on support to rural development by the European 
Agricultural Fund for Rural Development, available at: http://eur-lex.europa.eu/ LexUriServ/LexUriServ.do?uri=OJ:L:2013:347:0487:0548:en:PDF

12. European Parliament: Article 19 of Regulation (EU) no 1305/2013 of the European Parliament and of the Council on support to rural development by the European Agricultural Fund for Rural Development availableat: http://eur-lex.europa.eu/ LexUriServ/LexUriServ.do?uri=OJ:L:2013:347:0487:0548:en:PDF

13. European Regional Development Fund-ERDF (2014): Measure 112-Setting up of Young Farmers. Progress snapshot 2013/update May 2014, Available at: http:// enrd.ec.europa.eu/enrdstatic/app templates/enrd assets/pdf/measure-informationsheets/C-Infosheet 112.pdf

14. Hočevar-Knežević, D. (2012): Family farms in Slovenia: Who did the measures „Setting Up of Young Farmers" and „Early Retirement" actually address?, Antropological Notebooks, Vol. 18, No. 1, pp. 65-89

15. Kazakopoulos, L., Gidarakou, I. (2003): Young women farm heads in Greek agriculture: entering farming through policy incentives, Journal of Rural Studies, Vol. 19, No. 4, pp. 397-410

16. Marković, K., Njegovan, Z., Pejanović, R. (2012): Former and Future Reforms of Common Agriculture Policy of the European Union, Economics of agriculture, Vol. 59, No. 3, pp. 483-498

17. Tolić, S., Pušić, S. (2010): Application of science in sustainable rural development creation, Agrarian and Rural Policy in Serbia-3-Sustainability of Agrarian Economy, Cooperatives and Rural Areas, Serbian Association of Agricultural Economists, Faculty of Agriculture, University of Belgrade, pp. 283-298

18. Van Der Gaag, N., de Beer, J. (2015): From Demographic Dividend to Demographic Burden: The Impact of Population Ageing on Economic Growth in Europe, Tijdschrift voor Economische en Sociale Geografie, Vol. 106, No. 1, pp. 94-109

19. Vapa Tankosić, J., Stojsavljević, M. (2014): EU Common agricultural policy and pre-accession assistance measures for rural development, Economics of agriculture, Vol. 61, No. 1, pp. 195-210

20. Zagata, L., Sutherland, L.(2015): Deconstructing the „young farmer problem in Europe“: Towards a research agenda, Journal of Rural Studies, No. 38, pp. 39-51 


\title{
MEHANIZMI PODRŠKE MLADOJ RURALNOJ POPULACIJI U EVROPSKOJ UNIJI
}

\author{
Katarina Đurić3 ${ }^{3}$ Zoran Njegovan ${ }^{4}$
}

\begin{abstract}
Rezime
Sagledavanje postojećih i budućih mehanizama podrške mladim farmerima u Evropskoj uniji predstavlja osnovni cilj ovog rada. Pozitivni efekti mera politike ruralnog razvoja, ali $i$ ograničenja u njihovoj operacionalizaciji analizirani su na osnovu uvida $u$ aktuelne literaturne izvore i zakonsku regulativu Evropske unije. Ključne preporuke za vođenje politike ruralnog razvoja u njenom segmentu koji se fokusira na pitanja mlade populacije, odnose se na veći stepen participacije mladih ljudi u kreiranju razvojnih programa i projekata, pojednostavljenje administrativnih procedura i veću dostupnost informacijama. Posebna ograničena potencijalnih mladih farmera vezuju se za otežan pristup zemljištu i sistem finansiranja zasnovan na refundaciji investicionih sredstava.
\end{abstract}

Ključne reči: politika ruralnog razvoja, Evropska unija, mladi farmeri, ruralna populacija

3 Docent, dr Katarina Đurić, Univerzitet u Novom Sadu, Poljoprivredni fakultet Novi Sad, Trg Dositeja Obradovića br. 8, Telefon: +381 21485 32 32, E-mail: katarina.djuric@polj.uns.ac.rs

4 Redovni profesor, dr Zoran Njegovan, Univerzitet u Novom Sadu, Poljoprivredni fakultet Novi Sad, Trg Dositeja Obradovića br. 8, Telefon: +381 21485 33 93, E-mail: njegovan@polj.uns.ac.rs 